Int. J. Morphol.,

32(1):208-213, 2014.

\title{
Morphometric Study of Pterion in Dry Human Skull Bones of Nigerians
}

\author{
Estudio Morfométrico del Pterion en Huesos del Cráneo Humano Secos de Nigerianos
}

Eboh, D. E. O. \& Obaroefe, M.

EBOH, D. E. O. \& OBAROEFE, M. Morphometric study of pterion in dry human skull bones of Nigerians. Int. J. Morphol., 32(1):208213, 2014.

SUMMARY: The pterion is an important landmark on the side of the skull as it overlies both the anterior branch of the middle meningeal artery and the lateral cerebral fissure intracranially. The study was carried out to determine the pterion types and define its distances to some neighboring structures in dry human skulls of Southern Nigerians. The study comprised 50 dry human skulls of unknown sex and age obtained from selected Nigerian Universities. Sutural patterns of the pterion on both sides of each skull based on the description of Murphy (1956), were observed and recorded. Distances of the pterion to neighboring structures were also measured using digital vernial caliper. Data obtained were subjected to statistical analysis using descriptive statistics and chi-square contingency table with the aid of the statistical package for social sciences (SPSS) version 16. P<0.05 is considered statistically significant. Results showed that the most common type of Pterion in Nigerian skulls was sphenoparietal. There was no significant association between side of the head and pterion type. The mean distance of the pterion to the frontozygomatic suture was $31.56 \pm 2.47 \mathrm{~mm}$ taking both side together, (left side $=31.08 \pm 2.24 \mathrm{~mm}$; right side $=32.06 \pm 2.62 \mathrm{~mm}$ ). The mean distance of the pterion to the midpoint of the zygomatic arch was $39.87 \pm 3.16 \mathrm{~mm}$ taking both sides together (left side $=39.52 \pm 3.32 \mathrm{~mm}$; right side $=40.22 \pm 2.98 \mathrm{~mm}$ ). The mean distance of the pterion to the glabella was $77.51 \pm 4.08 \mathrm{~mm}$ taking both side together (left side $=76.74 \pm 4.27 \mathrm{~mm}$; right side $=78.27 \pm 3.77 \mathrm{~mm}$ ). This will be useful in Surgery, Anthropology and for assessing the location of the pterion in incomplete archeological remains or forensic materials.

KEY WORDS: Pterion; Temporal fossa; Sphenoparietal; Frontotemporal; Stellate, Epipteric.

\section{INTRODUCTION}

The temporal fossa is an important area of the skull that is bounded inferiorly by the zygomatic arch, superiorly and posteriorly by the temporal lines on the calvaria, and anteriorly by the frontal process of the zygomatic bone (Standring et al., 2005). The frontal and parietal bones, the greater wing of the sphenoid, and the squamous part of the temporal bones form the floor of the temporal fossa. These four bones meet on each side of the head at a small circular area of sutures called pterion (Standring et al.).

Standring et al. reported that the pterion is an important landmark on the side of the skull as it overlies both the anterior branch of the middle meningeal artery and the lateral (Sylvian) cerebral fissure intracranially. They also stated that it usually lies $3 \mathrm{~cm}$ above the zygomatic arch and $3.5 \mathrm{~cm}$ behind the frontozygomatic suture. Moore \& Dalley (2006) reported that the pterion is two fingers' breadth superior to the zygomatic arch and a thumb's breadth poste- rior to the frontal process of the zygomatic bone. A hard blow to the side of the head may fracture the thin bones forming the pterion, with eventual rupture of this artery crossing the pterion. The hematoma resulting exerts pressure on the underlying cerebral cortex, with dire consequences if untreated for a few hours (Moore \& Dalley). The pterion is also known as the Sylvian point. It corresponds to the site of the anterolateral (sphenoidal) fontanelle on the neonatal skull, which disappears about three months after birth (Standring et al.).

It has been reported that the pterion is also an important landmark for the anterior branch of the middle meningeal artery, Broca's area (44-45), the insula, and the stem of the lateral sulcus. It is also a primary site during surgery to gain access to the sphenoid ridge and optic canal (Saxena et al., 2003). The pterion is also commonly used in cranial suture closure methodology as an important guide

\footnotetext{
"Department of Human Anatomy and Cell Biology, Faculty of Basic Medical Sciences, College of Health Sciences, Delta State University, Abraka, Nigeria.
} 
for age estimation and sex determination in archeological and forensic specimens (Lovejoy et al., 1985).

Various classifications of pterion have been proposed (Murphy, 1956; Wang et al., 2006). The pterion was first classified into three types (sphenoparietal, frontotemporal and stellate) by Broca in 1875 (Saxena et al., 2003). Murphy defined four types (sphenoparietal, frontotemporal, stellate, and epipteric) while Wang et al. gave six classifications (sphenoparietal,frontotemporal, stellate, epipteric, zygomaticoparietal and zygomaticotemporal).

The present study was conducted to determine the pterion types and define its distances to neighboring structures in dry human skulls of Southern Nigerians. The study will be of interest to anthropologists and forensic pathologists. It will be useful for assessing the location of the pterion in incomplete archeological remains or forensic materials.

\section{MATERIAL AND METHOD}

This was a descriptive anthropometric study carried out between February and July, 2012, in the Department of Anatomy and Cell Biology, Delta State University, Abraka, Nigeria. The study comprised 50 dry human skulls of unknown sex and age, obtained from the museums of department of Anatomy in Anambra State University, Uli, NnamdiAzikiwe University, Owerri, University of Benin, Benin City, Ambrose Alli University, Ekpoma, Niger Delta University, Wilberforce Island and Delta State University, Abraka.

This study was done by determining the sutural patterns of the pterion on both sides of each skull based on the description of Murphy (Fig. 1A-D). The sphenoparietal type was defined as a sutural pattern in which the sphenoid

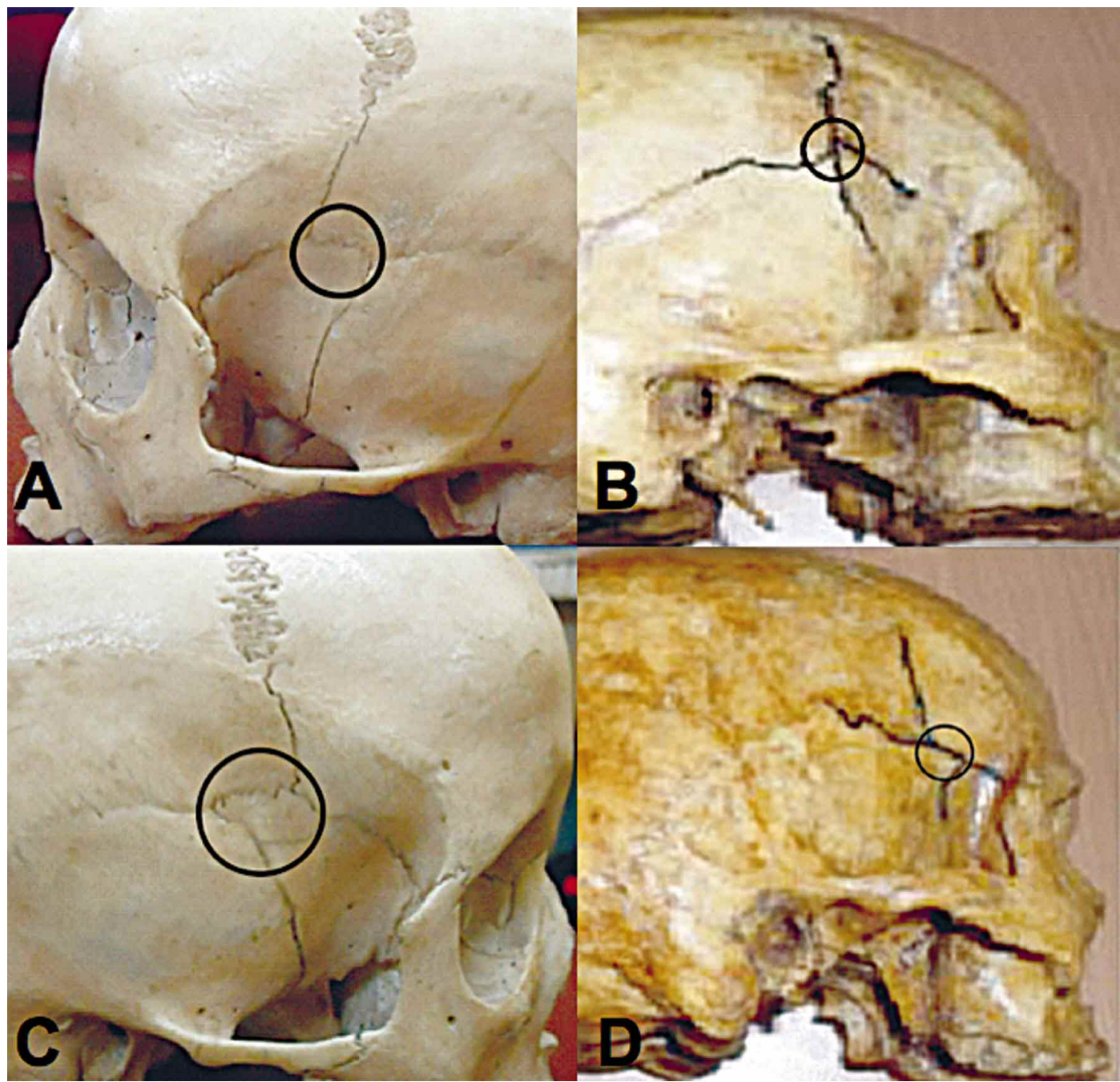

Fig. 1. A. Sphenoparietal type of pterion, B. Stellate type of pterion, C. Epipteric type of pterion and D. Frontotemporal type of pterion. 
and parietal bones are in direct contact (Fig. 1A). The frontotemporal type is a sutural pattern in which the frontal and temporal bones are in direct contact (Fig. 1D). The stellate type is characterized by articulation of four bones (frontal, parietal, temporal and sphenoid) at a point (Fig. 1B). The epipteric type was defined by presence of a small sutural bone between the parietal bone and the greater wing of the sphenoid bone (Fig. 1C).

Measurements were taken in millimeters on both sides of the skull from the pterion $(\mathrm{P})$ to the midpoint of the zygomatic arch (M); to the posterolateral aspect of the frontozygomatic suture (F); and to the glabella (G) (Fig. 2), using a digital vernier caliper (ORION, Japan). Each of the measurements was taken twice and the average taken to minimize error of measurements.

Skulls with regular shape, without obvious evidence of dystrophy, deformities and trauma were selected. Criteria of exclusion were those in which the pterion pattern could not be clearly identified, owing to breakage or fusion of adjacent bones (synostosis). Approval for this study was obtained from the Research Ethics Committee of the College of Health Sciences, Delta State University, Abraka, Nigeria.

The data obtained were subjected to statistical analysis using frequency distribution, descriptive statistics and chi-square contingency table with the aid of the statistical package for social sciences (SPSS) version 16. $\mathrm{P}<0.05$ was considered statistically significant.

\section{RESULTS}

Table I shows the frequency distribution of the pterion types on both sides of the skull. The four types of pterion (sphenoparietal, frontotemporal, stellate and epipteric) were observed in the Nigerian skulls. The dominant pterion type was sphenoparietal $(83.0 \%)$ taken when both sides of the skull were taken together (left side $=84.0 \%$, right side $=$

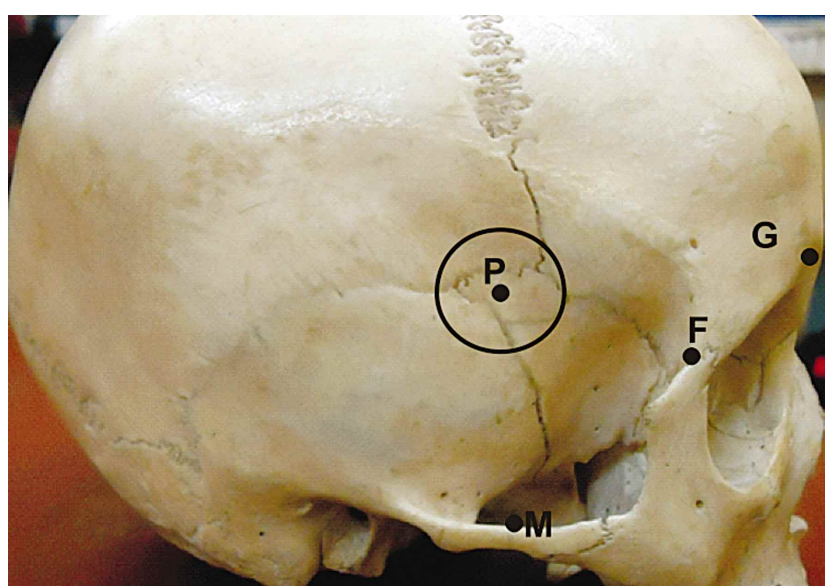

Fig. 2. Showing distances of pterion to neighbouring structures. $\mathrm{PF}=$ Pterion - Frontozygomatic Suture; PM = Pterion -Midpoint of Zygomatic Arch; PG = Pterion - Glabellar.

$82.0 \%)$. This is followed by stellate $(6.0 \%)$, (left side $=6.0 \%$, right side $=6.0 \%)$; epipteric $(6.0 \%)$, (left side $=4.0 \%$, right side $8.0 \%$ ) and the frontotemporal $(5.0 \%)$ (left side $=6.0 \%$, right side $=4.0 \%$ ).

Table II shows the result of test of association between pterion type and side using chi-square contingency table. The chi-square test for degree of association between pterion type and side of the skull was not statistically significant $(\mathrm{P}>0.05)$.

Table III shows the descriptive statistics of the distance between the pterion and frontozygomatic suture (PFZS), midpoint of the zygomatic arch (PMPZ) and the glabella (PG). The mean distance between the pterion and the frontozygomatic suture was $31.56 \pm 2.47 \mathrm{~mm}$ taking both side together, (left side $=31.08 \pm 2.24 \mathrm{~mm}$; right side $=32.06 \pm 2.62$ $\mathrm{mm})$. The mean distance of the pterion to the midpoint of the zygomatic arch was $39.87 \pm 3.16 \mathrm{~mm}$ taking both sides together (left side $=39.52 \pm 3.32 \mathrm{~mm}$; right side $=40.22 \pm 2.98 \mathrm{~mm}$ ). The mean distance between the pterion and to the glabella was $77.51 \pm 4.08 \mathrm{~mm}$ taking both side together (left side $=$ $76.74 \pm 4.27 \mathrm{~mm}$; right side $=78.27 \pm 3.77 \mathrm{~mm}$ ).

Table I. Frequency distribution of types of pterion observed on both sides of the skull.

\begin{tabular}{|c|c|c|c|c|c|}
\hline \multirow{2}{*}{ Pterion Type } & \multirow{2}{*}{\multicolumn{2}{|c|}{ Total }} & \multicolumn{3}{|c|}{ Si de } \\
\hline & & & & Left & Right \\
\hline S ph en oparietal & 83 & $(83.0 \%)$ & 42 & $(84.0 \%)$ & $41(82 \%)$ \\
\hline Fron to ptemporal & 5 & $(5.0 \%)$ & 3 & $(6.0 \%)$ & $2(4.0 \%)$ \\
\hline Stellate & 6 & $(6.0 \%)$ & 3 & $(6.0 \%)$ & $3(6.0 \%)$ \\
\hline Epipteric & 6 & $(6.0 \%)$ & 2 & $(4.0 \%)$ & $4(8.0 \%)$ \\
\hline
\end{tabular}


Table II. Chi-square contingency table between pterion type and side.

\begin{tabular}{|c|c|c|c|c|c|c|}
\hline \multirow{2}{*}{ P terion Ty pe } & \multicolumn{2}{|c|}{ Si de } & \multirow{2}{*}{ Total } & \multirow{2}{*}{$\mathbf{X}^{2}$} & \multirow{2}{*}{ df } & \multirow{2}{*}{$\mathbf{P}$} \\
\hline & $L$ ef $t$ & R ig ht & & & & \\
\hline Sphenoparietal & $42(50.6 \%)$ & $41(49.4 \%)$ & $83(100 \%)$ & & & \\
\hline Fro nt ot emp oral & $3(60 \%)$ & $2(40 \%)$ & $5 \quad(100 \%)$ & & & \\
\hline St ellate & $3(50 \%)$ & $3(50 \%)$ & $6 \quad(100 \%)$ & 0.879 & 3 & 0.831 \\
\hline Epipteric & $2(33.3 \%)$ & $4 \quad(66.7 \%)$ & $6 \quad(100 \%)$ & & & \\
\hline Total & $50(50 \%)$ & $50(50 \%)$ & $100(100 \%)$ & & & \\
\hline
\end{tabular}

Table III. Descriptive statistics of dimensions measured between the pterion and some structures.

\begin{tabular}{llccccc}
\hline Si de & Parameters & n & Minimum & M ax imu m & Mea n & S D \\
\hline \multirow{4}{*}{ Total } & P FZS (m m) & 100 & 26.20 & 37.63 & 31.57 & 2.47 \\
& P MPZ (m m) & 100 & 30.22 & 49.10 & 39.87 & 3.16 \\
& PG (m m) & 100 & 65.13 & 87.23 & 77.51 & 4.08 \\
\multirow{3}{*}{ Left } & P FZS (m m) & 50 & 26.20 & 36.92 & 31.08 & 2.24 \\
& P MPZ (m m) & 50 & 30.22 & 49.10 & 39.52 & 3.32 \\
& PG (m m) & 50 & 65.13 & 87.23 & 76.74 & 4.18 \\
& P FZS (m m) & 50 & 26.35 & 37.63 & 32.06 & 2.62 \\
& P MPZ (m m) & 50 & 33.31 & 47.79 & 40.22 & 2.98 \\
& PG (m m) & 50 & 68.48 & 86.38 & 78.27 & 3.77 \\
\hline
\end{tabular}

\section{DISCUSION}

In the present study, four Types of pterion: sphenoparietal, frontotemporal, stellate and epipteric were observed in Nigerian skulls. The dominant type of pterion was Sphenoparietal (83\%). This was followed by stellate $(6.0 \%)$, epipteric $(6.0 \%)$ and the least was frontotemporal $(5.0 \%)$.

Previous studies also showed dominance of Sphenoparietal type in different populations. In South Indian, Manjunath et al. (1993), reported 93.55\% while Praba \& Venkatramanah (2012) reported sphenoparietal to be $76.5 \%$; in North Indian, Saxena et al. (2003), reported 84.72\%; in Western Indian, Zalawadia et al. (2010), reported 91.7\%. In other Indian studies, Hussain Saheb et al. (2011), noted the sphenoparietal type of pterion to be $69.25 \%$ while Natekar et al. (2011), reported $85.33 \%$. In a Korean study, Lee et al. (2001), reported $76.5 \%$. In a Turkish study, Oguz et al. (2004), reported 88\%. In a Thai study, Apinhasmit et al. (2011) reported sphenoparietal to be $81.2 \%$. In a Kenyan study, Mwachaka et al. (2009), reported 66\%. In a study, Saxena et al. (1988) reported $95.3 \%$ for Indians and $87.79 \%$ for Nigerians. In Nigeria, Asala \& Mbajiorgu (1996), reported $82.1 \%$. It has been opined that the high occurrence of the sphenoparietal pterion could have an evolutionary basis (Hussain Saheb et al.).
With regard to the other three type of pterion, the percentage distribution varies with population. Our findings are in accordance with Praba \& Venkatramanah, who reported that stellate type was $6.0 \%$, epipteric $(6.0 \%)$ and the least was frontotemporal (3.0\%). Others differ. Manjunath \& Thomas (1993), reported epipteric (17.3\%), frontotemporal (3.52\%) and stellate (2.93\%). Saxena et al. (2003), reported frontotemporal (10.01\%), stellate $(5.17 \%)$ and epipteric (0\%). Zalawadia et al. reported epipteric (4.8\%), frontotemporal (2.4\%), stellate (1.2\%). Lee et al. reported epipteric $(40.3 \%)$ while frontotemporal stellate were nil. Oguz et al. reported frontotemporal (10\%), stellate (0\%) and epipteric (2\%). Mwachaka et al. reported frontotemporal (15\%), epipteric (12\%) and stellate (7\%). Saxena et al. (1988), reported epipteric (11.79\%), frontotemporal (3.46\%) and stellate $(1.38 \%)$ for Indians; and frontotemporal $(10.11 \%)$, stellate $(5.06 \%)$ and epipteric $(3.79 \%)$. Asala \& Mbajiorgu (1996), reported frontotemporal (23.6\%), epipteric (5.7\%) and stellate was nil.

The chi-square test for degree of association between pterion type and side was not statistically significant $(\mathrm{P}=0.831)$. This indicates that side of the head has no influence on type of pterion. This result is in agreement with (Apinhasmit et al., 2011), who reported no statistically 
significant association between pterion type and side. Also in agreement with Murphy, who carried out a study of pterion in the Australian aborigine and reported no side influence on the occurrence of pterion type.

In the present study, the mean distance between the pterion and the posterior aspect of the frontozygomatic suture was $31.56 \pm 2.47 \mathrm{~mm}$ taking both sides together (31.08 $\pm 2.24 \mathrm{~mm}$ on the left side and $32.06 \pm 2.62 \mathrm{~mm}$ on the right side). These findings are in tandem with (Williams et al., 1998) who described the pterion to lie between 30 to $35 \mathrm{~mm}$ away from the frontozygomatic suture. This result is higher than that of (Mwachaka et al.) who reported that the pterion on was located $30.35 \pm 3.40 \mathrm{~mm}$ posterior to the frontozygomatic suture on the right while the left was $30.34 \pm 4.30 \mathrm{~mm}$ behind. It is also higher than that of Appinhasmit et al., who reported the pterion to be located $31.12 \pm 4.89 \mathrm{~mm}$ posterior to the frontozygomatic suture taken both side together. These findings are lower than of Oguz et al., who reported the pterion to lie $33.0 \pm 4.0 \mathrm{~mm}$ and $34.4 \pm 3.9 \mathrm{~mm}$ behind the frontozygomatic suture on the right and left side respectively in Turkish male skull. This result is also lower than Zalawadia et al., who observed in his study that the pterion was located $35.5 \pm 0.42$ $\mathrm{mm}$ behind the frontozygomatic suture on the left side and $37.3 \pm 0.51 \mathrm{~mm}$ on the right side. The basis for the differences could be racial, geopolitical, genetic or evolutionary (Ikedo et al., 1999).

In the present study, the mean distance between the pterion and the midpoint of zygomatic arch was $39.87 \pm 3.16$ $\mathrm{mm}$ taking both sides together; $39.52 \pm 3.32 \mathrm{~mm}$ on the left side; $40.22 \pm 2.98 \mathrm{~mm}$ on the right. These findings are higher than Mwachaka et al., who reported the pterion to be located $38.56 \pm 3.28 \mathrm{~mm}$ above the midpoint of the zygomatic arch. It is also higher than that of Apinhasnit et al., who reported the pterion to be located $38.48 \pm 4.38 \mathrm{~mm}$ superior to the midpoint of the zygomatic arch on both sides of the skulls of Thailand. It is also higher than Oguz et al., who reported the pterion to be located $3.85 \pm 0.25$ $\mathrm{cm}$ on left side and $4.05 \pm 0.39 \mathrm{~cm}$ on right side from the midpoint of zygoma in Turkish skulls. It is also higher than Zalawadia et al., who reported the pterion to be $29.7 \pm 0.33 \mathrm{~mm}$ and $31.2 \pm 0.44 \mathrm{~mm}$ superior to the midpoint of the zygomatic arch on the left and right side of the skulls respectively in Gujarat region. The basis for these differences could be genetic or environmental. The variation in distance in the different studies may be due to genetics, nutrition, geographic and environmental factors.

In the present study, the mean distance of the pterion to the glabella was $77.51 \pm 4.08 \mathrm{~mm}$ taking both sides together, $76.74 \pm 4.27 \mathrm{~mm}$ on the left side; $78.27 \pm 3.77 \mathrm{~mm}$ on the right side.

\section{CONCLUSION}

The most common type of Pterion in Nigerian skulls was sphenoparietal. There was significant association between side of the head and pterion type. The mean distance of the pterion to the posterior aspect of the frontozygomatic suture was $31.56 \pm 2.47 \mathrm{~mm}$. The mean distance of the pterion to the midpoint of zygomatic arch was $39.87 \pm 3.16 \mathrm{~mm}$. The mean distance of the pterion to the glabella was $77.51 \pm 4.08 \mathrm{~mm}$. This will be useful in Surgery and Anthropology.

EBOH, D. E. O. \& OBAROEFE, M. Estudio morfométrico del pterion en huesos del cráneo humano seco de nigerianos. Int. J. Morphol., 32(1):208-213, 2014.

RESUMEN: El pterion es un importante marcador del lado del cráneo, ya que se superpone a la rama anterior de la arteria meníngea media y a la cisura cerebral lateral por vía intracraneal. El estudio se realizó para determinar el tipo de pterion y definir las distancias con algunas estructuras cercanas, en cráneos humanos secos de nigerianos del Sur. Se utilizaron 50 cráneos humanos sin información de sexo y edad, obtenidos de Universidades. Fueron observados y registrados los patrones suturales del pterion en ambos lados de cada cráneo, basados en la descripción de Murphy en 1956. También se midieron las distancias del pterion hacia estructuras cercanas utilizando un cáliper digital. Los datos obtenidos fueron sometidos a análisis estadístico mediante estadística descriptiva y prueba de chi cuadrado con el programa estadístico SPSS versión 16. Un valor $\mathrm{P}<0,05$ se consideró significativo. El tipo más común de pterion en cráneos de Nigeria fue esfenoparietal. No hubo asociación significativa entre el lado del cráneo y el tipo pterion. La distancia media del pterion a la sutura frontocigomática fue $31,56 \pm 2,47 \mathrm{~mm}$ (al lado izquierdo $=31,08 \pm 2,24 \mathrm{~mm}$, al derecho $=32,06 \pm 2,62 \mathrm{~mm}$ ). La distancia media del pterion hasta el punto medio del arco cigomático fue 39,87 $\pm 3,16 \mathrm{~mm}$ (al lado izquierdo $=39,52 \pm 3,32 \mathrm{~mm}$; al derecho $=40,22 \pm 2,98 \mathrm{~mm}$ ). La distancia media del pterion a la glabela fue 77,51 $\pm 4,08 \mathrm{~mm}$ (al lado izquierdo $=76,74 \pm 4,27 \mathrm{~mm}$, al derecho $=78,27 \pm 3,77 \mathrm{~mm}$ ). Esta información es útil para la cirugía y antropología, así como también en la evaluación de la ubicación del pterion en restos arqueológicos incompletos o material forense.

PALABRAS CLAVE: Pterion; Fosa temporal; Esfenoparietal; Frontotemporal; Estrellado; Epiptérico. 


\section{REFERENCES}

Apinhasmit, W.; Chompoopong, S.; Chaisuksunt, V.; Thiraphatthanavong, P. \& Phasukdee, N. Anatomical consideration of pterion and its related references in Thai dry skulls for pterional surgical approach. J. Med. Assoc. Thai., 94(2):205-14, 2011.

Asala, S. A. \& Mbajiorgu, F. E. Epigenetic variation in the Nigerian skull: sutural pattern at the pterion. East Afr. Med. J., 73(7):4846, 1996.

Hussain Saheb, S.; Mavishetter, G. F.; Thomas, S. T.; Prasanna, L. C.; Muralidhar, P, \& Magi. A study of sutural morphology of the pterion and asterion among human adult Indian skulls. Biomed. Res., 22(1):73-5, 2011.

Ikeda, T.; Nakamura, M. \& Itoh, M. Sex differences in the zygomatic angle in japanese patients analyzed by MRI with reference to Moiré fringe patterns. Aesthetic Plast. Surg., 23(5):349-53, 1999.

Lee, U. Y.; Park, D. K.; Kwon, S. O.; Paik, D. J. \& Han, S. H. Morphological analysis of the pterion in Korean. Korean $J$. Phys. Anthropol., 14(4):281-9, 2001.

Lovejoy, C. O.; Meindl, R. S.; Mensforth, R. P. \& Barton, T. J. Multifactorial determination of skeletal age at death: a method and blind tests of its accuracy. Am. J. Phys. Anthropol., 68(1):1$14,1985$.

Manjunath, K. Y. \& Thomas, I. M. Pterion variants and epipteric ossicles in South Indian skulls. J. Anat. Soc. India, 42:85-94, 1993.

Moore, K. L. \& Dalley, A. F. Clinical Oriented Anatomy. $5^{\text {th }}$ ed. Philadelphia, Lippincott Williams \& Wilkins, 2006. pp.887903.

Murphy, T. The pterion in the Australian aborigine. Am. J. Phys. Anthropol., 14(2):225-44, 1956.

Mwachaka, P. M.; Hassanali, J. \& Odula, P. Sutural morphology of the pterion and asterion among adult Kenyans. Braz. J. Morphol. Sci., 26(1):4-7, 2009.

Natekar, P. E.; DeSouza, F. M. \& Natekar, S. P. Pterion: An anatomical variation and surgical landmark. Indian J. Otol., 17(2):83-5, 2011.

Oguz, O.; Sanli, S. G.; Bozkir, M. G. \& Soames, R. W. The pterion in Turkish male skulls. Surg. Radiol. Anat., 26(3):220-4, 2004.

Praba, A. M. A. \& Venkatramaniah, C. Morphometric Study of different types of Pterion and It's relation with middle meningeal artery in dry skulls of Tamil Nadu. J. Pharm. Biomed. Sci., 21(21):1-4, 2012.
Saxena, R. C.; Bilodi, A. K.; Mane, S. S. \& Kumar, A. Study of pterion in skulls of Awadh area--in and around Lucknow. Kathmandu Univ. Med. J. (KUMJ), 1(1):32-3, 2003.

Saxena, S. K.; Jain, S. P. \& Chowdhary, D. S. A comparative study of pterion formation and its variations in the skulls of Nigerians and Indians. Anthropol. Anz., 46(1):75-82, 1988.

Standring, S.; Ellis, H.; Healy, J. C. \& Johnson, D. Gray's AnatomyThe Anatomical Basis of Clinical Practice. 39th ed. London, Elsevier Churchill Livingstone, 2005. pp.441-84.

Wang, Q.; Opperman, L. A.; Havil, L. M.; Carlson, D. S. \& Dechow, P. C. Inheritance of sutural pattern at the pterion in Rhesus Monkey skulls. Anat. Rec. Discov. Mol. Cell. Evol. Biol., 288(10):1042-9, 2006.

Williams, L. P.; Bannister, L. H.; Berry, M. M.; Collins, P.; Dyson, M.; Dussek, J. E.; \& Ferguson, M. W. J. Gray's Anatomy. 38th ed. London, Churchill Livingstone, 1998.

Zalawadia, D. A.; Vadgama, D. J.; Ruparelia, D. S.; Patel, D. S. \& Patel, D. S. V. Morphometric study of pterion In dry skull of Gujarat Region. Natl. J. Integrated Res. Med., 1(4):25-9, 2010.

\section{Correspondence to:}

Dr. Dennis E.O. Eboh

Department of Human Anatomy and Cell Biology

Faculty of Basic Medical Sciences

College of Health Sciences

Delta State University, P.M.B. 1

Abraka

NIGERIA

Tel: +2348033872254

Email: drebohdennis@yahoo.com

Received: 17-05-2013

Accepted: 19-11-2013 